\title{
ECOLOGICAL PRACTICES AS AN ELEMENT OF THE ENVIRONMENTAL MANAGEMENT OF POLISH SMES
}

\author{
Aleksandra Koszarek-Cyra \\ Czestochowa University of Technology \\ Faculty of Management
}

\begin{abstract}
The article is an attempt to present environmentally-friendly actions of Polish small and medium-sized business sector as an element of environmental management in business entities. In the first part the essence and genesis of environmental management have been characterized, in the second one trends, barriers and determinants of proenvironmental actions of the SMEs in Poland have been indicated. The analysis has been based on statistical data obtained in the survey 'Flash Eurobarometer 426. SMEs, resource efficiency and green markets', which was carried out on behalf of the European Commission, Directorate-General for Internal Market, Industry, Entrepreneurship and SMEs in September 2015.
\end{abstract}

Keywords: environmental management, SMEs, ecological activities

DOI: $10.17512 /$ znpcz.2016.1.19

\section{Introduction}

The conflict between the condition of the environment and human activity has always existed, but it began to be especially noticeable with the development of industrial enterprises (Poskrobko2007, p. 256). In the fifties of the 20th century the awareness of the adverse impact of the human activity on the environment began to be an issue widely discussed on the international forum. The public began to pay increasing attention to the growth of air pollution, soil degradation or the problem of depletion of natural resources. This growing concern about the state of the environment caused a revolution in the approach to the issues of its protection and contributed to an increase in the number of ecological practices in organizations. (Leonidou et al. 2013) As the years passed pro-environmental strategies began to be not only a domain of international corporations or large enterprises but also became a part of the management of smaller organizations such as SMEs.

\section{Genesis of environmental management - chronological approach}

For the past half-century the approach of enterprises to environmental issues has changed radically. The evolution proceeded from the state of total absence of taking into account environmental protection in the activity of business entities, by gradually increasing the commitment, to the implementation of environmental management in overall enterprise management system. 


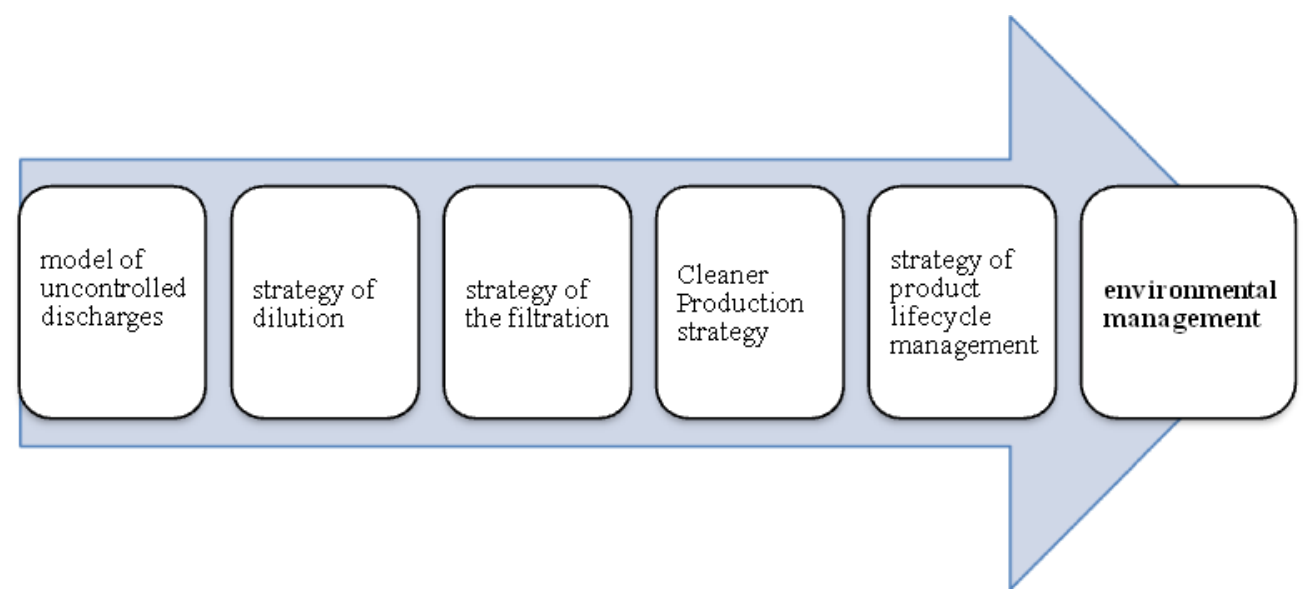

Figure 1. Genesis of environmental management

Source: Own elaboration based on Wiśniewska, 2004.

In the nineteenth and the first decades of the twentieth century, there was no attention paid to influence of the industry on the state of the natural environment. During this period enterprises carried out the model of the wasteful exploitation of natural resources and uncontrolled discharge of waste, which resulted in pollution of groundwater, soil and the formation of illegal waste dumps.

In the fifties of the twentieth century, when enterprises began to attach importance to environmental protection, companies began to apply the strategy of dilution, as a way to reduce anthropopression. The essence of this idea was the decrease in pollution by dilution of the sewage, which was produced in technological processes, so that the environment could absorb contaminants. This strategy was inefficient because ecosystems were not able to assimilate such an amount of waste.

The next step in the development of green initiatives was starting to use a various type of filters so-called end-of-pipe technologies (strategy of filtration), which was intended to reduce the amount of pollutants. However, this strategy also did not bring the expected results, and also generated the problem of utilization and neutralization of waste separated in filters (Gajdzik, Wyciślik 2010, pp. 81-82).

In the eighties of the twentieth century, it was concluded that the reduction of waste at the production stage is a more environmentally favorable approach than its minimization at the "end of pipe". Cleaner Production Strategy (CP) was introduced, its main idea was to prevent waste at the source - in the production process.

The nineties of the twentieth century brought a revolutionary change in the approach to environmental protection by enterprises. A new concept, called the strategy of product lifecycle management, assumed that the reduction of emissions of pollutants and amount of waste is not only associated with the production process, but also with its sale, consumption or exploitation and using postconsumer waste (Wiśniewska 2004, pp. 91-98). 
In 1992, during the United Nations Conference on Sustainable Development (UNCSD) in Rio de Janeiro, a document was signed by 1,200 companies, which contained 25 principles of responsible business. Sixteen of them were directly related to the impact of business activities on the environment. It was the base document for the later standards and procedures of the environmental management.

In the same year the International Organization for Standardization (ISO) joined the work on a worldwide environmental management procedure. It led to appearance, in 1996, of the norm ISO 14001 - an environmental management system (Poskrobko 2007, p. 255)

From that moment on environmental management slowly began to be implemented in integral management systems.

Today, as Brzozowska and Starostka-Patyk (2008) indicate combination of management science and environmental protection with the practice of business operation in order to use and protect enviroment more reasonably become more and more popular.

\section{Environmental management of enterprises}

Nowadays, when the idea of Sustainable Development, defined in the report of the World Commission on Environment and Development (1987) as the economic and social development, which will satisfy the needs of the contemporary generation without the risk that future generations will not be able to satisfy their needs, is considered as a leading concept, increasing pressure is being exerted on enterprises to limit their negative impact on the environment. This pressure comes from various sources, on the one hand, it is conditioned by the law regulations on the other hand is the result of requirements of increasingly environmentally sensitive customers and business partners. The principles of corporate social responsibility, stakeholders` requirements and the increasing demand for green products and services are the cause of growing interest in the subject of sustainability of organizations among the managers and entrepreneurs (Zorpas 2010). As a result of it, environmental management is increasingly treated as an integral part of the process of creating the organization's strategy (Berrone, GomezMejia 2009).

According to the definition B. and T. Poskrobko (2012, p. 16), environmental management is managing the processes of the use, protection and forming of the environment. It includes organizational structure, planning, procedures, processes and resources for implementing and operating management in a way which takes into account environmental problems.

Implementation of environmental management functions include: planning, conducting and monitoring the effects of ecological actions in enterprises. Such actions are initiatives associated with the use of preventing and controlling pollution technology, optimizing production and distribution processes towards reducing resource and energy consumption, environmental training for employees and implementation of environmental management systems (EnMS). 
The level of actions intensity depends on the degree of environmental involvement of organizations. Entrepreneurs represent two attitudes towards environmental management. The first one, chosen by less involved companies, characterized by low pro-ecological activity, consisting almost exclusively in meeting legal obligations; the second one - presented by environmentally engaged companies, involves an active pro-ecological approach, in which activities extend far beyond the legal obligation and include, for example: the creation of departments responsible for environmental activities, implementation of environmental objectives in the policy of the organization, obtaining environmental certificates and awards etc. (Nath, Ramanathan 2016). The first type of organization Henriques and Sadorsky (1999) call entities reactive (reactive), the other proactive, Hunt and Auster (1990) use the nomenclature "begginers" (type 1) and "proactivist" (type 2).

In the literature, 4 types of market strategies, chosen by the companies in the field of environmental management, can be found. Their essence presents the diagram below.

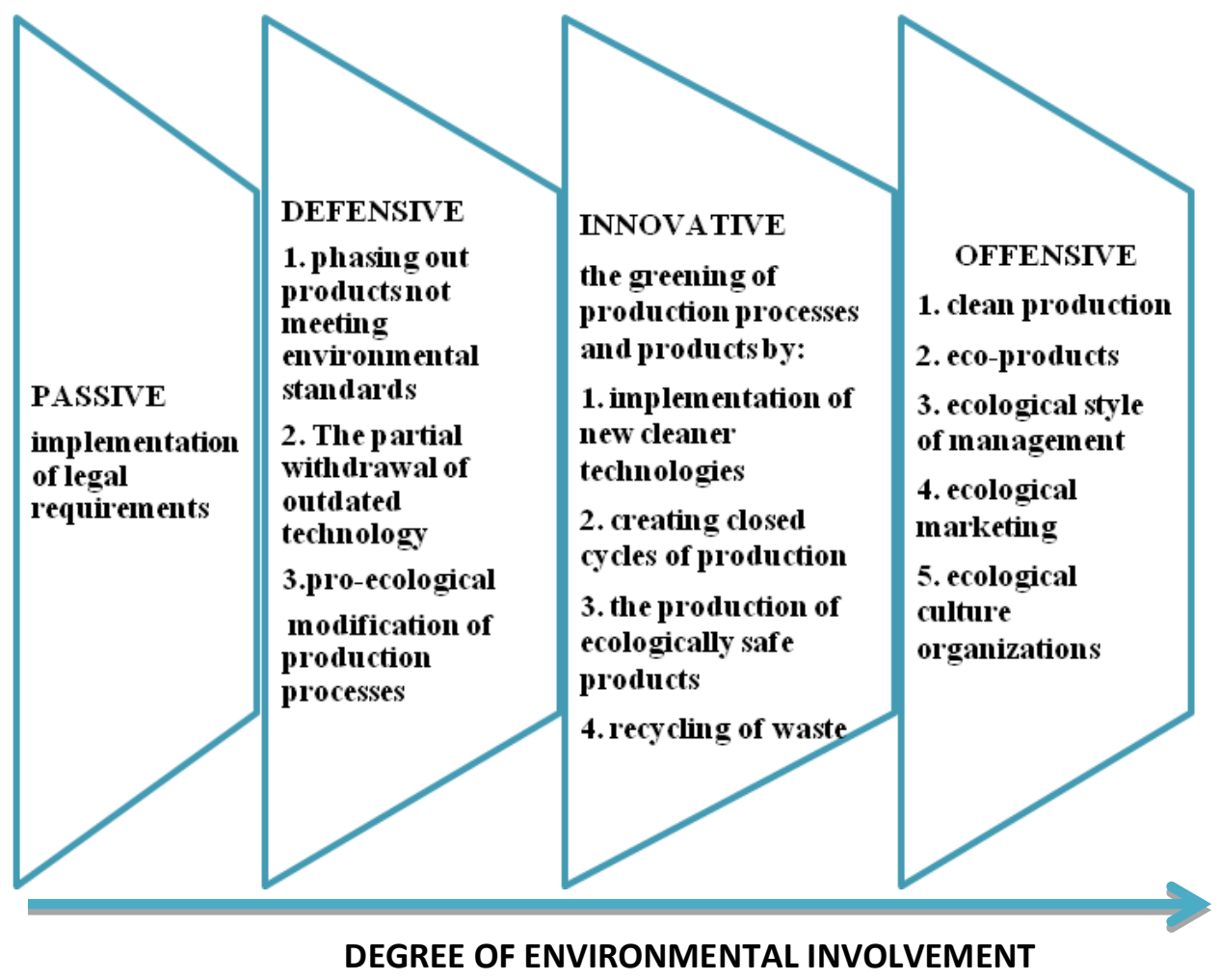

Figure 2. Market environmental strategies depending on the degree of involvement of the organization

Source: Own elaboration based on Gajdzik,Wyciślik, 2010. 


\section{Environmental management of the SMEs sector}

According to the Commission Regulation (EC) No 800/2008 of 6 August 2008 the category of micro, small and medium-sized enterprises ('SMEs') is made up of enterprises which employ fewer than 250 persons and which have an annual turnover not exceeding EUR 50 million, and/or an annual balance sheet total not exceeding EUR 43 million. An additional criterion taken into account, for example, in the User guide to the SME definition (2015) is dependence of the company on other organizations. It is assumed that the share of other entities may not exceed $25 \%$ (contribution of shares, the right to participate in the profits, votes at the general meeting of shareholders).

The SME sector is the basis - "backbone" of the European and Polish economy.

In 2014 Poland there were 1.8 million of non-financial companies belonging to the SMEs sector. Similarly to previous years, this sector had most of the domestic economy - SMEs represented 99, 8\% of all companies. (GUS 2015) Analyzing the impact of a single SME organization on the environment, it is usually minimal, but taking into account the cumulative environmental impact of the whole sector, it must be emphasized that it is crucial. Therefore, it is important to implement environmental management to small organizations rather than to treat it as the domain of only large enterprises. It should be emphasized that these actions in the SMEs sector cannot be synonymous with the activities of large companies or corporations. This is primarily due to differences in the structure and culture of the organization, but also to the availability of resources. (Bos-Brouwers 2010; Sinha, Akoorie 2010)

It should be remembered that carrying out environmental activities frequently requires financial resources, small entities often do not have own resources to support these initiatives, especially for those which go beyond legal requirements and are often perceived by management as unnecessary, not-bringing measurable benefits (Mir, Feitelson 2007).

The problem, especially for microenterprises, in which environmental issues are the responsibility of the owner/managing director, could be the lack of time for ecological activities. It may result from a multitude of other duties, as well as lack of knowledge and the perception of environmental initiatives as economically insignificant (Zorpas 2010).

\section{Environmental activities of Polish SMEs sector}

In this subsection the author will attempt to present environmental activities of Polish SME sector. The analysis is based on statistical data obtained in the survey conducted on behalf of the Directorate-General for Internal Market, Industry, Entrepreneurship and SMEs, European Commission, in $28 \mathrm{EU}$ countries and Albania, Macedonia, Montenegro, Serbia, Turkey, Iceland, Moldova, Norway and USA, by TNS Political \& Social network in September 2015 (Flash Eurobarometer 426 database Poland 2015).

In Poland, the study was conducted by TNS OBOP and included 500 SMEs (440 microenterprises, 51 small and 9 medium-sized enterprises). Data from 2015 was compared with information obtained in the analogous study, which was conducted in September 2013. (Flash Eurobarometer 381 database Poland, 2013). 
As the most frequently undertaken pro-environmental initiatives, respondents mentioned the initiatives related to saving materials and reduction of energy consumption. These two types of activities entrepreneurs also indicated most often in 2013. Compared to the previous survey, the number of activities in the field of waste minimization has increased. It is disturbing, that almost $1 / 5$ of companies do not undertake any ecological actions, and the percentage of enterprises introducing changes decreased by $10 \%$ within two years (Fig. 3).

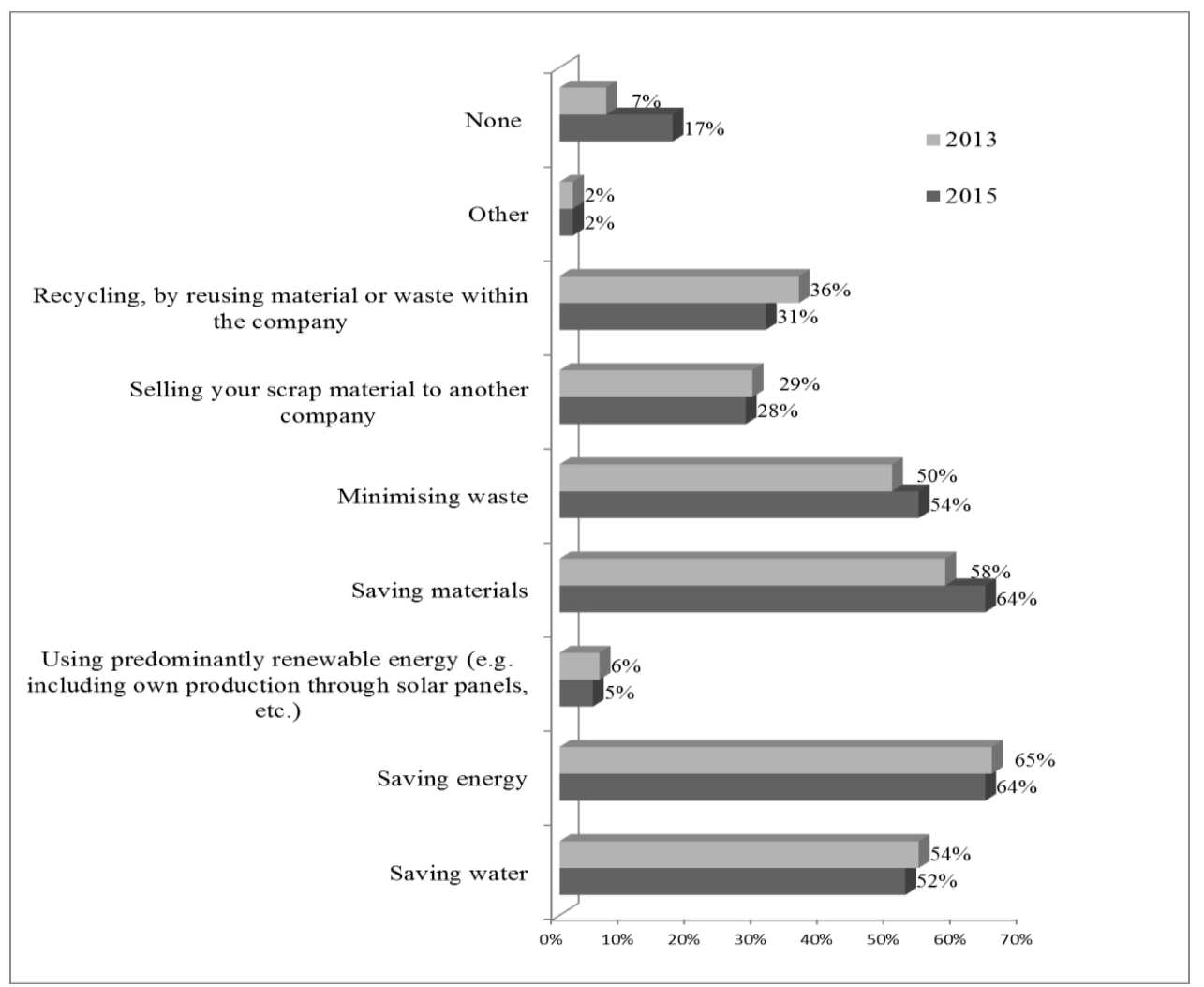

Figure 3. Pro-environmental actions taken by the SME sector in 2011-2015

Source: Own elaboration based on Flash Eurobarometer 426 - POLAND database.

Analyzing the sector, it may be noted, that while the implementation of actions by microenterprises remained at a similar level as in 2013, and in the case of material savings this percentage even increased by 9 percentage points, the medium-sized companies significantly reduced the frequency of implementing changes. Particularly noticeable is the decrease in the number of investments in energy and materials saving, but also in other types of activity the number of initiatives significantly decreased. 
Table 1. Ecological activities according to size of enterprises

\begin{tabular}{|c|c|c|c|c|c|c|c|c|c|}
\hline & \multicolumn{3}{|c|}{ Micro-enterprises } & \multicolumn{3}{|c|}{ Small enterprises } & \multicolumn{3}{|c|}{ Medium enterprises } \\
\hline Action & 2015 & 2013 & $\begin{array}{c}\text { The } \\
\text { change } \\
\text { compared } \\
\text { to the } \\
2013 \\
\end{array}$ & 2015 & 2013 & $\begin{array}{c}\text { The } \\
\text { change } \\
\text { compared } \\
\text { to the } \\
2013\end{array}$ & 2015 & 2013 & $\begin{array}{c}\text { The } \\
\text { change } \\
\text { compared } \\
\text { to the } \\
2013\end{array}$ \\
\hline Saving water & $52 \%$ & $54 \%$ & $-2 \%$ & $51 \%$ & $50 \%$ & $1 \%$ & $42 \%$ & $66 \%$ & $-24 \%$ \\
\hline Saving energy & $65 \%$ & $63 \%$ & $2 \%$ & $55 \%$ & $68 \%$ & $-13 \%$ & $48 \%$ & $88 \%$ & $-40 \%$ \\
\hline $\begin{array}{l}\text { Using } \\
\text { predominantly } \\
\text { renewable energy } \\
\text { (e.g. including } \\
\text { own production } \\
\text { through solar } \\
\text { panels, etc.) }\end{array}$ & $5 \%$ & $5 \%$ & $0 \%$ & $3 \%$ & $14 \%$ & $-11 \%$ & $8 \%$ & $12 \%$ & $-4 \%$ \\
\hline Saving materials & $64 \%$ & $55 \%$ & $9 \%$ & $60 \%$ & $64 \%$ & $-4 \%$ & $49 \%$ & $86 \%$ & $-37 \%$ \\
\hline Minimising waste & $54 \%$ & $48 \%$ & $6 \%$ & $50 \%$ & $56 \%$ & $-6 \%$ & $48 \%$ & $60 \%$ & $-12 \%$ \\
\hline $\begin{array}{l}\text { Selling scrap } \\
\text { material to } \\
\text { another company }\end{array}$ & $27 \%$ & $25 \%$ & $2 \%$ & $28 \%$ & $42 \%$ & $-14 \%$ & $40 \%$ & $53 \%$ & $-13 \%$ \\
\hline $\begin{array}{l}\text { Recycling, by } \\
\text { reusing material } \\
\text { or waste within } \\
\text { the company }\end{array}$ & $32 \%$ & $36 \%$ & $-4 \%$ & $22 \%$ & $33 \%$ & $-11 \%$ & $28 \%$ & $45 \%$ & $-17 \%$ \\
\hline Other & $2 \%$ & $1 \%$ & $1 \%$ & $1 \%$ & $3 \%$ & $-2 \%$ & - & - & \\
\hline None & $17 \%$ & $8 \%$ & $9 \%$ & $18 \%$ & $4 \%$ & $14 \%$ & $45 \%$ & - & \\
\hline
\end{tabular}

Source: Own elaboration based on Flash Eurobarometer 426 - POLAND database.

The study shows that the majority of entities do not invest large funds in environmental activities. 30\% the organizations declared that, during 2013-2015, they allocated no financial outlays for pro-ecological activity, while almost $60 \%$ of respondents indicated, that they dedicated to it less than $10 \%$ of annual turnover. Comparing the data with this obtained in 2013, it can be concluded that the activities carried out by entrepreneurs belong to the low-cost sector. 


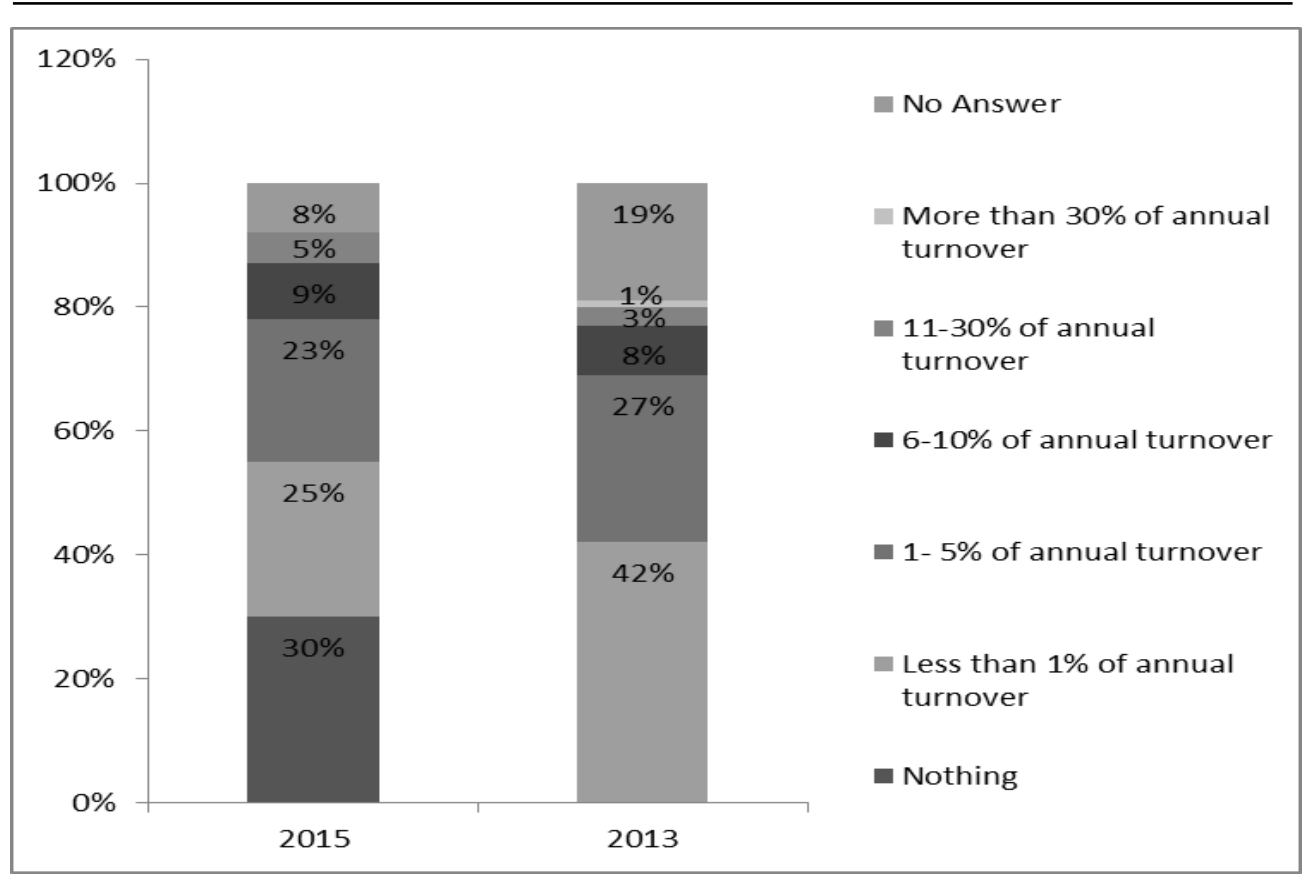

Figure 4 The amount of funds for pro-environmental actions in SMEs

Source: Own elaboration based on Flash Eurobarometer 426 - POLAND database.

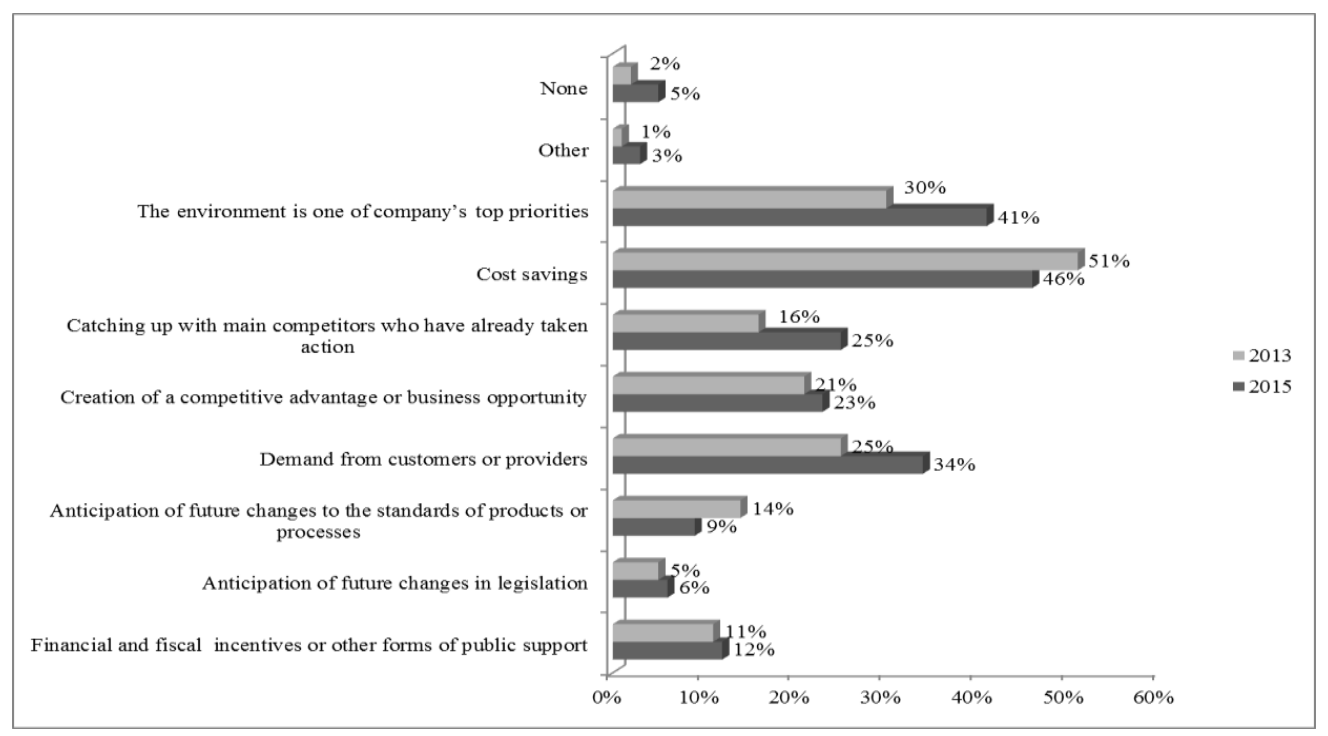

Figure 5. Reasons for taking environmental actions

Source: Own elaboration based on Flash Eurobarometer 426 - POLAND database 
As two years earlier, as the main reason for taking actions, respondents indicated a reduction of operating costs. More often than before, condition of the environment was recognized as one of the main priorities in the organization. Entrepreneurs attached greater importance to ecological requirements of customers and business partners, as well as to the necessity of catching up with the competition, which had already introduced changes.

Table 2. Reasons for taking environmental actions according to size of enterprises

\begin{tabular}{|c|c|c|c|}
\hline Reasons & $\begin{array}{c}\text { Micro- } \\
\text { enterprises }\end{array}$ & Small enterprises & $\begin{array}{c}\text { Medium } \\
\text { enterprises }\end{array}$ \\
\hline $\begin{array}{c}\text { Financial and fiscal } \\
\text { incentives or other forms } \\
\text { of public support }\end{array}$ & $12 \%$ & $10 \%$ & $27 \%$ \\
\hline $\begin{array}{c}\text { Anticipation of future } \\
\text { changes in legislation }\end{array}$ & $5 \%$ & $6 \%$ & $13 \%$ \\
\hline $\begin{array}{c}\text { Anticipation of future } \\
\text { changes to the standards } \\
\text { of products or processes }\end{array}$ & $8 \%$ & $13 \%$ & $16 \%$ \\
\hline $\begin{array}{c}\text { Demand from customers } \\
\text { or providers }\end{array}$ & $34 \%$ & $29 \%$ & $52 \%$ \\
\hline $\begin{array}{c}\text { Creation of a competitive } \\
\text { advantage or business } \\
\text { opportunity }\end{array}$ & $21 \%$ & $30 \%$ & $\mathbf{4 7 \%}$ \\
\hline $\begin{array}{c}\text { Catching up with main } \\
\text { competitors who have } \\
\text { already taken action }\end{array}$ & $24 \%$ & $39 \%$ & $21 \%$ \\
\hline Cost savings & $46 \%$ & $42 \%$ & $53 \%$ \\
\hline $\begin{array}{c}\text { The environment is one of } \\
\text { company's top priorities }\end{array}$ & $\mathbf{4 2 \%}$ & $38 \%$ & $29 \%$ \\
\hline Other & $3 \%$ & $6 \%$ & - \\
\hline None & $6 \%$ & $1 \%$ & - \\
\hline
\end{tabular}

Source: Own elaboration based on Flash Eurobarometer 426 - POLAND database

Within the sector, the possibility of creating a competitive advantage was more often pointed out as a motivator for medium-sized companies (almost half of them indicates that reason), while smaller organizations demonstrated greater concern for environmental protection.

Research has shown that entrepreneurs more often encountered obstacles in the implementation of pro-environmental actions than in previous years. The percentage of respondents declaring problems was higher in all groups of analyzed barriers 


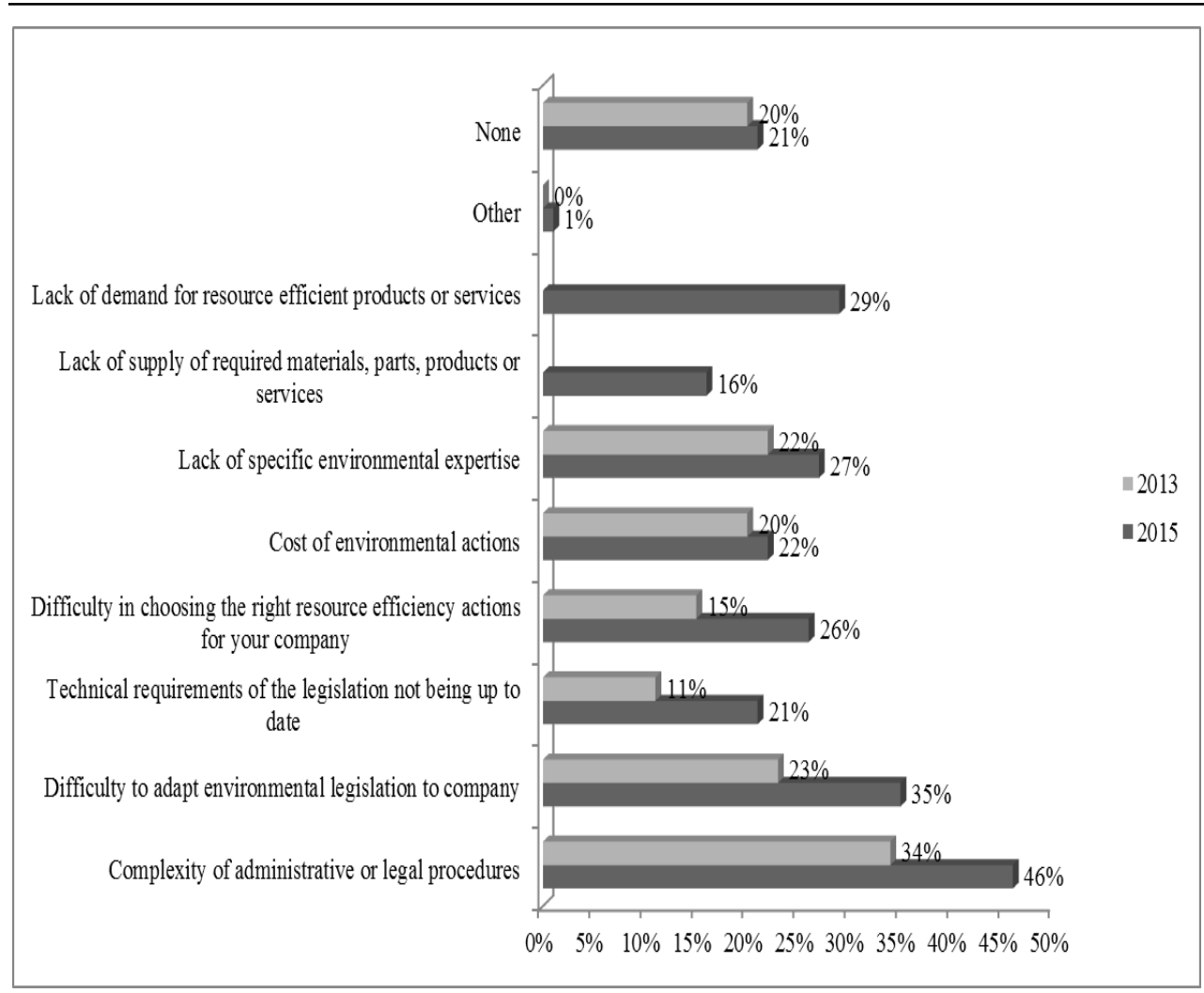

Figure 6. Difficulties in the implementation of pro-environmental actions

Source: Own elaboration based on Flash Eurobarometer 426 - POLAND database

Particularly disturbing was the increase in the number of respondents indicating problems connected with the complexity of administrative or legal procedures and the difficulties of adapting environmental legislation to their companies. In both cases, the percentage of respondents increased by 12 points. An interesting fact is that $30 \%$ of entities observed the lack of interest in green services and products among customers or business partners, which may indicate low ecological awareness of the organization surrounding.

\section{Summary}

Global concerns about the exhaustion of natural resources, climate change, and the possibility of biodiversity loss are becoming increasingly important in business reality. There is no doubt that current legal regulations, applicable principles of corporate social responsibility and the stakeholders demands require that environmental management is an integral part of the development strategy of the organization. 
However, it should be remembered that SMEs are not smaller versions of large organizations and they may require different ways of dealing with environmental problems.

On that basis of the above analysis, it can be concluded that the implementation of an environmental management in general management system of Polish small companies is still in an initial phase. Furthermore, in the last two years, there was a regression in this process, because entrepreneurs more rarely undertook pro-environmental initiatives than before. It may have been caused by an increase in the number of encountered barriers, in particular the complexity of administrative and legal procedures.

It should be considered that whether the reason for taking actions is not an ecological motive but the possibility of cost reduction (even if they have a positive impact on the environment), they should be still treated as an element of environmental management.

\section{References}

1. Berrone P., Gomez-Mejia L. R., 2009. Environmental performance and executive compensation: an integrated agency-institutional perspective. Acad. Manag. J. 52 (1), pp. 103-126, DOI: 10.5465/AMJ.2009.36461950

2. Bos-Brouwers H. 2010. Corporate sustainability and innovation in SMEs: evidence of themes and activities in practice. Business Strategy and the Environment 19(7), pp. 417-435. DOI: $10.1002 / \mathrm{bse} .652$

3. Brzozowska and Starostka-Patyk 2008. Environmental Management and Reverse Logistics. [In] Advanced Logistic Systems. Theory and Practice. VOL.2 pp. 89-95. ISSN: 1789-2198

4. Commission Regulation (EC) No 800/2008 of 6 August 2008 declaring certain categories of aid compatible with the common market in application of Articles 87 and 88 of the Treaty, (General block exemption Regulation) Annex I

5. European Union, 2015,User guide to the SME definition, Luxembourg: Publications Office of the European Union, DOI: 10.2873/620234

6. Flash Eurobarometer 381 database, 2013. Available at: https://open-data.europa.eu/pl/data/ dataset/S1086_381 [30.03.2016]

7. Flash Eurobarometer 426 database 2015, Available at: https://open-data.europa.eu/pl/data/ dataset/S2088_426_ENG [30.03.2016]

8. Gajdzik B., Wyciślik A. 2010, Wybrane aspekty ochrony środowiska i zarzadzania środowiskowego, Gliwice: Wydawnictwo Politechniki Śląskiej ISBN: 978-83-7335-716-7

9. GUS, 2015. Działalność przedsiębiorstw niefinansowych $w 2014$ roku, Warszawa ISSN 1895 - 698X Available at: http://stat.gov.pl/obszary-tematyczne/podmioty-gospodarczewyniki-finansowe/przedsiebiorstwa-niefinansowe [30.03.2016]

10. Henriques I., Sadorsky P. 1999. The relationship between environmental commitment and managerial perceptions of stakeholder importance. Acad. Manag. J. 42(1), pp. 87-99. DOI: $10.2307 / 256876$

11. Hunt C. B., Auster E. R. 1990. Proactive environmental management: Avoiding the toxic trap. Sloan Manag. Rev. 31(2), pp.7-18.

12. Leonidou C. N., Leonidou L. C., Fotiadis T. A., Zeriti A. 2013. Resources and Capabilities as Drivers of Hotel Environmental Marketing Strategy: Implications for Competitive Advantage and Performance. Tourism Management 35, pp. 94-110. DOI: 10.1016/j.tourman.2012.06.003 
13. Mir D, Feitelson E. 2007. Factors affecting environmental behaviour in micro-enterprises: laundry and motor vehicle repair firms in Jerusalem. International Small Business Journal 25(4): 383-415. DOI: 10.1177/0266242607078583

14. Nath P., Ramanathan R., Environmental management practices, environmental technology portfolio, and environmental commitment: A content analytic approach for UK manufacturing firms. Int. J. Production Economics 171 (2016) pp. 427-437 DOI: 10.1016/j.ijpe.2015.09.040

15. Poskrobko B. 2007 Zarzadzanie środowiskiem, Warszawa: PWE ISBN:978-83-208-1713-3

16. Poskrobko B., Poskrobko T. 2012 Zarzadzanie środowiskiem w Polsce. Warszawa: PWE ISBN: 978-83-208-2011-9

17. Report of the World Commission on Environment and Development: Our Common Future. Available at:. http://www.un-documents.net/our-common-future.pdf [30.03.2016]

18. Sinha P, Akoorie M. 2010. Sustainable environmental practices in the New Zealand wine industry: an analysis of perceived institutional pressures and the role of exports. Journal of Asia-Pacific Business 11(1): 50-74. DOI: 10.1080/10599230903520186

19. Wiśniewska A. 2004 Strategie proekologiczne $w$ zarzadzaniu przedsiębiorstwem. [In] M. Kistowski (ed..), Studia ekologiczno-krajobrazowe $w$ programowaniu rozwoju zrównoważonego. Przegląd polskich doświadczeń u progu integracji z Unia Europejska, Gdańsk: Bogucki Wydawnictwo Naukowe, pp. 91-98. ISBN 83-89290-32-4

20. Zorpas A. 2010. Environmental management systems as sustainable tools in the way of life for the SMEs and VSMEs. Bioresource Technology 101 (2010) pp. 1544-1557 DOI:10.1016/j.biortech.2009.10.022

\section{DZIALANIA PROEKOLOGICZNE JAKO ELEMENT ZARZĄDZANIA ŚRODOWISKOWEGO W PRZEDSIĘBIORSTWACH POLSKIEGO SEKTORA MSP}

Streszczenie: W niniejszym artykule podjęta została próba przedstawienia działań proekologicznych polskiego sektora MSP jako elementów zarządzania środowiskowego w podmiotach gospodarczych. Scharakteryzowano istotę i genezę zarządzania środowiskowego, jak również na podstawie danych statystycznych publikowanych przez Komisję Europejską wskazano trendy, bariery i determinanty działań prośrodowiskowych organizacji sektora MSP w Polsce

Słowa kluczowe: zarządzanie środowiskowe, MSP, działania proekologiczne 